\title{
Improving Students' Vocabulary Achievement through Anagram
}

\author{
Rina Herawati Barus ${ }^{1}$, Jonris Tampubolon ${ }^{2}$ \\ Universitas Prima Indonesia Medan \\ john89tpb@gmail.com
}

\begin{abstract}
This study is aimed at improving the students' vocabulary achievement through anagram. This study was conducted by using classroom action research. The subject of this study was the 2009/2010 ten grade students of SMA Negeri 1 Pancur Batu which consisted of 30 students. For collecting data, the instrument used quantitative data (vocabulary test) and qualitative data (diary notes, interview sheet and observation sheet). Based on the data, it was found that the students' score increased from the pre test until the post test of the first and the second cycle. In the pre test, the mean of the students was $(54,93)$, in the post test of the first cycle was (68) and the mean of the students of the second cycle was $(82,46)$. The students' score also increased from pre test to post test cycle I until post test cycle II. It was found that teaching vocabulary through anagram can improve the students' vocabulary achievement. It is concluded that teaching vocabulary through anagram is significantly effective in teaching vocabulary.
\end{abstract}

\section{Keywords: Classroom Action Research, Vocabulary Achievement, Anagram}

\section{Introduction}

The learners, in order to communicate well in English, they have to acquire English that involve four skills, namely listening, speaking, reading, and writing. But, being able to master those skills, the learners need vocabulary.

"Vocabulary is the basic elements in achieving all four language skills. In using the language, the learners who are rich in vocabulary will be successful both in expression skill: speaking and writing and receptive skill: reading and listening. But one who is poor in vocabulary will get trouble in those skills." (Deignton, 1971:461) Vocabulary and grammar are both important. With a bigger number of vocabularies, the learners will be able to talk about more things; with a better grammar, the learners will be able to talk fluently and more accurately. Vocabulary is more important than grammar, because it is a word, which carries the content of what we want to say. Grammar joins group of word together, but most of the meaning is in the words.

According to McCarthy, "No matter how well the learners learn grammar, or how successful the sounds of the languages are mastered, without words communication can not occur in any meaningful way".

Based on the writer's experience in teaching practice in Senior High School level and based on the writer's interview and observation at SMU N.1. Pancur Batu, in a class, most of the students are passive because they do not know a lot of vocabularies. Although they seemed having some ideas in their mind, but they could not express their idea because they have lack of vocabulary So far, teacher's technique used in teaching vocabulary is not interesting or monotonous. She/he usually gives many new words to the students and asks them to translate those words and then make sentences by using the given words. So, when the teaching learning process takes place, the students 
did not give attention and feel bored. Because of that, the English teacher must have the ability to use various teaching method. It is necessary for English teacher to understand their students' vocabulary learning strategies.

There are some methods in teaching (Richard, 1985:12), which are designed to provide a detailed account of major twentieth century trends in language teaching. One of them is Anagram. Anagram is fun and interesting way to learn vocabulary or spelling words. Anagram is a word by transposing letters of one word to form another.

The writer hopes, after learning vocabulary by using anagram, the students can enjoy their studying and increase the students' vocabulary continually and hopefully enjoy their foreign language learning.

The objective of the research is to find out whether the students' vocabulary achievement improved if they are taught by applying Anagram technique?"

\section{Conceptual Framework}

A vocabulary is defined as "all the words known and used by a particular person". A person's vocabulary is the set of words they are familiar with in a language. Learning a language means learning its vocabularies. We use the vocabularies in communication either in spoken form or written form. We try to send messages, share information and ideas by using the language. In general, no language acquisition is possible without understanding the vocabulary, either in the first or the second language. "Vocabulary is one of the components of language and that no language exists without words". (Pieter, 1991:6)

An anagram [New Latin anagramma, from Greek anagrammatismos, from anagrammatize in, to rearrange letters in a word: ana- 'again' + gramma 'letter'] is a type of word play, rearranging the letters of a word or phrase to produce a new word or phrase by using all the original letters exactly once. Anagram is one of fun and interesting ways to learn vocabulary or spelling words. Students may also have fun figuring out list of words in which the letters are scrambled.

The term "anagram" according to Collins (2003) is a word or phrase of the letters which can be rearranged into another word or phrase. Anagram is word by transposing letters of one word to form another. This is in line with Merriam -Webster (1913) who asserts that anagram is the change of one word or phrase into another by the transposition of its letters.

Anagram is a type of word play in which a word or phrase is formed by rearranging the letters of another word or phrase, such as united to untied (Richard, 2010). Today, anagram is used by the teacher to the language teaching especially in teaching vocabulary. It is believed that using anagram will give the students enjoyment or challenge in studying language and encourage them to look carefully at words, students can practice to form another words from the given clues, match words with definition, provide spelling practice, show the students how the letters of many words can be manipulated to form other words, emphasize the importance of letter position in relation to word meaning. It is clear that anagram is an interesting way of learning to increase one's vocabulary.

There are many kinds of word games, such as scrabble and puzzle. Anagram is faster paced and more productive than those word games, because anagram is focusing on word formation and vocabulary expansion through the use of affixes and compounds.

\section{Research Design}

This study applied Classroom Action Research (CAR). Small - scale classroom research implemented by teachers and directed at improving learning outcomes is called action research (Thornbury, 1995:139). Action research as the research design used in social and education sciences, primarily used for social science or reality. According to Wallace (1998:1), action 
research is defined as the systematic collection and analysis of data relating to the improvement of some area of professional field. The purposes of action research are to improve the quality of studying practice, to find solution and to solve the problem.

Action research is a dynamic process in which these four steps are to be understood not as static steps, complete in themselves, but rather as a moments in the action research spiral of planning, acting, observing, and reflecting.

Based on the statements above, it would be stated that classroom action research aims to improve students' learning and the outcomes of teaching learning process. It is an approach to improve teaching practice. Moreover, it concerns to four steps namely; planning, action, observation and reflection.

\section{The Data}

The subject of this study was the grades X-6 student of SMA. N. 1 P.Batu. This school consisted of eight parallel classes of ten grade students, namely $\mathrm{X}-1$ until $\mathrm{X}-8$. Each class approximately consisted of 30 students.

The sample was taken one class from eight class that is grade $X-6$. This class will be tested twice. First test was called pre test. This test will be given to the students before applying the technique. Second test was called post test. This test will be given after appplying the technique.

\section{The Instrument of Collecting Data}

This study collected quantitative and qualitative data. In collecting quantitative data, the researcher gave written assessments to the students as the instrument. It was to analyze the students' learning level. The students were asked to answer all the questions given. The questions had five parts. All the questions were answered by applying anagram; transposing or rearranging the letters of a word or phrase to produce a new word or phrase, using all the original letters exactly once.

In collecting qualitative data, the researcher used observation sheets focusing on what was happening in the classroom (classroom management) taken by the collaborator, interviewing the students to obtain about their interest and difficulties in learning vocabulary, diary notes to record events in a chronological events which showed thoughts and feelings important to the researcher, as the instrument.

\section{The Procedure of Research}

The procedure of data collection of the study was conducted five meetings by administrating two cycles. Each cycle has four steps, namely planning, acting, observing, and reflecting.

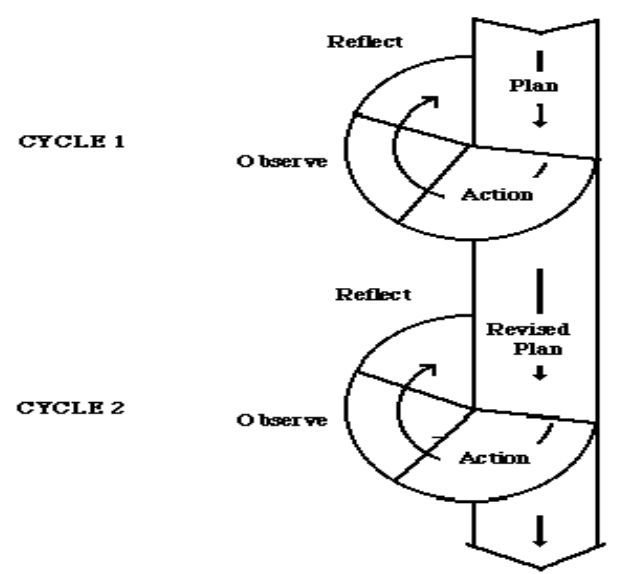

Figure 1 Simple Action Research Model (from MacIsaac, 1995)

Published by English Lecturers and Teachers Association (ELTA)

Copyright (C) 2022, authors 
The Procedure of Data Collection in each cycle can be seen as Follows:

\section{Cycle 1. Planning:}

1. Administrated the orientation test to obtain the level of students' current ability. The students were asked to transpose the letters of one word to another word, which consisting of twenty five items.

2. Prepared the lesson plan about improving students' vocabulary achievement by using anagram.

3. Prepared the equipments that were necessary, such as problem sheet/answer sheet.

4. Developed an observation sheet.

\section{Action:}

1. Implemented everything in the classroom that had been planned on the lesson plan that was about improving students' vocabulary achievement by using anagram.

2. Assigned the first test in cycle I to the students.

The test consisted of twenty five items, which was divided into five parts. Each part consisted of five items. The first part was forming another word from the key word; the second part was rearranging the letters in bracket after that fill in each blank with the appropriate anagram to complete the sentence;

The third part was omitting one or some letters of the key word and transposing the rest; the fourth part was transposing the letters of the word and form another word by using those letters exactly once based on the definition; the last part wrote in the blank the names of things hidden in the words and phrases appropriate to the clue.

\section{Observing:}

1. Checked the observing sheet by checklist the observation format.

2. Took the diary notes and wrote all of the action that happened in the classroom.

It was done to know the students' interest in learning vocabulary by using anagram and to know the influence of anagram technique in improving students' vocabulary achievement.

\section{Reflecting:}

1. Did the evaluation of teaching and learning process.

2. Reflected and evaluated what had been done.

\section{In cycle 2:}

1. The researcher changed, revised and conformed the scenario of teaching and learning process in the classroom.

2. Gave the second test (last test).

\section{Reliability of The Test}

Brown (1988:154) says that reliability is the test designed as the extent to which the result can be considered consistent or stable. In this study, Pearson Product Moment is used to know the reliability of the the whole test whether reliable or not.

\section{The Technique for Analyzing Data}

The data analysis of the study was divided into two. They were analysis of the quantitative data and analysis of the qualitative data. The quantitative data were taken from the result of the test that consisted of twenty five items of vocabulary test. The vocabulary test score was taken from the orientation test, first test, and second test. 
The result of students' score could be seen in the following table:

Table 1 The Students' Vocabulary Score.

\begin{tabular}{|c|c|c|c|c|}
\hline \multirow{2}{*}{ No } & \multirow{2}{*}{ Students Initial } & \multirow{2}{*}{$\begin{array}{c}\text { Orientation } \\
\text { Test }\end{array}$} & \multicolumn{2}{|c|}{ Students' Score } \\
\hline & & & First Test & Second Test \\
\hline 1 & ASP & 76 & 80 & 92 \\
\hline 2 & $\mathrm{AP}$ & 64 & 76 & 84 \\
\hline 3 & AS & 48 & 60 & 72 \\
\hline 4 & CRP & 52 & 76 & 88 \\
\hline 5 & DRP & 48 & 56 & 76 \\
\hline 6 & DL & 40 & 56 & 80 \\
\hline 7 & DSR & 44 & 56 & 76 \\
\hline 8 & $\mathrm{DCN}$ & 76 & 80 & 88 \\
\hline 9 & DTY & 48 & 60 & 80 \\
\hline 10 & ES & 56 & 76 & 88 \\
\hline 11 & ECG & 44 & 56 & 80 \\
\hline 12 & $\mathrm{~EB}$ & 40 & 56 & 76 \\
\hline 13 & $\mathrm{HL}$ & 64 & 76 & 84 \\
\hline 14 & HV & 76 & 80 & 88 \\
\hline 15 & IK & 76 & 84 & 92 \\
\hline 16 & IV & 76 & 80 & 92 \\
\hline 17 & IS & 44 & 60 & 76 \\
\hline 18 & $\mathrm{LS}$ & 36 & 56 & 68 \\
\hline 19 & MK & 76 & 84 & 92 \\
\hline 20 & NL & 44 & 60 & 88 \\
\hline 21 & NRS & 76 & 80 & 92 \\
\hline 22 & SM & 64 & 76 & 84 \\
\hline 23 & SO & 60 & 72 & 84 \\
\hline 24 & SGN & 36 & 56 & 70 \\
\hline 25 & $\mathrm{SDM}$ & 40 & 60 & 84 \\
\hline 26 & WPD & 36 & 56 & 76 \\
\hline 27 & WY & 36 & 52 & 72 \\
\hline 28 & YD & 76 & 88 & 92 \\
\hline 29 & YS & 56 & 76 & 88 \\
\hline \multirow[t]{2}{*}{30} & FR & 40 & 56 & 72 \\
\hline & $\sum X$ & 1648 & 2040 & 2474 \\
\hline & $X$ & 54,93 & 68 & 82,46 \\
\hline
\end{tabular}

1. In the orientation test, the total score of the students was and the number of the students was 30 , so the mean is:

$$
X=\frac{\sum X}{N} \times 100 \%=\frac{1648}{30} \times 100 \%=54,93 \%
$$

2. In the first test, the total score of the students was and the number of the students was 30 , so the mean is:

$$
X=\frac{\sum X}{N} \times 100 \%=\frac{2040}{30} \times 100 \%=68 \%
$$


3. In the second test (last test), the total score of the students was and the number of the students was 30 , so the mean is:

$$
X=\frac{\sum X}{N} \times 100 \%=\frac{2474}{30}=82,46 \%
$$

The mean of the students' score in the first test was higher than the orientation test. The students' vocabulary increased from $68 \%$ to $54,93 \%$. follows:

The Percentage of the improvement students' vocabulary through anagram could be seen as

1. $P_{1}=\frac{8}{30} \times 100 \%=26,66 \%$

2. $P_{2}=\frac{15}{30} \times 100 \%=50 \%$

3. $P_{3}=\frac{25}{30} \times 100 \%=83,33 \%$

Table 2 The percentage of the students' vocabulary Test

\begin{tabular}{ccc}
\hline Test & Percentage & Number of Students \\
\hline Orientation & $26,66 \%$ & 8 \\
I & $50 \%$ & 15 \\
II & $83,33 \%$ & 25 \\
\hline
\end{tabular}

The result showed the improvement of the students' score from the orientation test to the first test of cycle I, first test cycle 1 to the second test (last test). When the orientation test was conducted to the students, there were only $26,66 \%$ or 8 students who got the score above 75 . In the first test, which was conducted to the students in cycle 1 of action research, there were $50 \%$ or 15 students who got the score above 75 . It meant there was an improvement of the students in their vocabulary about $23,33 \%$ compared with the first orientation test.

In the second test (last test) which was conducted to the students in cycle 2 of action research, there were $83,33 \%$ or 25 students who got the score above 75 . It meant there was an improvement of students in their vocabulary about 33, 33\% compared with the first test. So, the use of anagram to improve students' vocabulary could be said worked well.

The qualitative data were taken from the diary notes, interview sheet and observation sheet. In the qualitative data, both teacher and students' behavior were evaluated during the process of teaching and learning.

\section{Research Findings}

a. The result of this research indicated that there was an improvement on students' vocabulary achievement which was taught by using anagram. It was proved by the data which showed that the mean of the students in the second cycle/second test $(82,46)$ was higher than that of the first cycle/ first test (68) and also higher than that of the orientation test $(54,93)$.

b. The qualitative data that were taken from diary notes, observation sheet, and interview also showed that the students' achievement increased.

\section{Conclusion}

Based on the research findings, it was found out that the students' score increased from the orientation test until the first test and the last test (second test). It meant that there was an improvement on the students' vocabulary achievement by using anagram. It was shown from the 
quantitative data, the mean of the orientation test $(54,93)$ improved to the mean of the first test $(68)$ and the mean of the second test $(82,46)$. It can be stated that the score was continually improved from the orientation test until the last test in cycle II.

Finally, it can be concluded that the use of anagram during the teaching and learning process in the classroom can improve students' vocabulary achievement and based on the qualitative data that consisted of diary notes, interview sheet and observation sheet, it can be concluded that the students felt interested to learn vocabulary through anagram.

\section{References}

Abel, MA. 2002. Competence Based Curiculum for SMU Students Achievement Indicator Indexes on the Basic of the Competencies, penerbit Jakarta

Bahri, M.A.SE.2010. Teaching English Vocabulary Using Games. (http://www.scribd.com/doc/9639825/teaching - english - vocabulary - using - games) accessed on $3^{\text {rd }}$ April 2010

Brown, Doughlas. H. 1980. Principles of Language Learning and Teaching. USA: University of Illinois.

Collins, William. 2003. Collins English Dictionary. Princeton University.

Croft, Kenneth. 1972. Reading on English As a Second Language. Cambridge: San Francisco State College.

Diba. 2002. (http://www.Depdiknas.co.id). Accessed on $3^{\text {rd }}$ April 2010.

Frank, Marcella. 1972. Modern English. USA: New York University.

Hastutik. 2009. Increasing Vocabulary Mastery. (http.//www.Increasing Vocabulary Mastery) accessed on February $2^{\text {nd }} 2010$.

Hornby, A. S. 1989. Oxford Advanced Learners' Dictionary of Current English. London: Oxford University Press.

Lado, Robert. 1988. Language teaching: A Scientific Approach. Chapter 12: "Live Words and Their Meaning." New York: McGraw - Hill, Inc

Longman Dictionary. 1978. Longman Active Study Dictionary. England.

MacIsaac, Dan. $1995 \quad$ "An Introduction to Action Research." http://www.phy.nau.edu/ danmac/actionrsch.html. Accessed on March $7^{\text {th }} 2010$

Macmillan, Collier. 1965. The Key to English Vocabulary. London: The Macmillan Company.

McCarthy, Michael. 1990. English Vocabulary in Use. Cambridge: University Press. 
Merriam. 1913. The Definition of Anagram. (http://www. Anagramterm.htm) accessed on February $2^{\text {nd }} 2010$.

Oxford, dictionary. 2003. Oxford Learners Pocket Dictionary. New York: University Press.

Pieter A, Napa. 1991. Vocabulary Development Skills. Yogyakarta: Kanisus.

Richards, J. C and T. S. Rodgers. 1988. Approaches and Method in Language Teaching. Cambridge: LUP.

Thornbury, Scott. 1995. How to teach Vocabulary. Longman. www. Anagramgenius. Com home page. Accessed on February 12 $2^{\text {th }} 2010$. http://www. Adprima. com/measurement.htm.

Wallace, Michael J. 1998. Action Research for Language Teachers. United Kingdom: Cambridge University. 